\title{
Examining the Connection amongst Renewable Energy, Economic Growth and Carbon Dioxide Emissions in Algeria*
}

\author{
Salah Eddine Sari Hassoun' 1 (D) , Mohammed Mékidiche ${ }^{2}$ (D) , Mohammed Seghir Guellil ${ }^{3}$ (D)
}

\begin{abstract}
In this paper, we shall study the relationship between renewable energy, economic growth (GDP), carbon dioxide emissions and with control variable that are estimated into realized volatility and to verify if the EKC hypothesis is accepted or not. This study is focussed on the Algerian situation during the periods of 1995-2016 and we employed the VECM procedure and Granger causality to estimate the short and long-run coefficients. We found with VECM that an increase in carbon dioxide emissions, fossil energy consumption and production will raise the level of economic growth, while an increase in GDP, fossil energy consumption and production will upsurge the level of carbon dioxide emissions, but an increase in renewable energy consumption will reduce both GDP and carbon dioxide emissions. We concluded in the short-term that there's bidirectional causality between carbon dioxide emissions and GDP and there is unidirectional causality running from renewable energy consumption to carbon dioxide emissions.
\end{abstract}

\section{Keywords}

Environment • Renewable Energy • Economic Growth • Carbon Dioxide Emissions • EKC Hypothesis • VECM Model - Granger Causality

\section{JEL Classifications}

$\mathrm{O} 13 \cdot \mathrm{P} 18 \cdot \mathrm{C} 32$

* http://siteresources.worldbank.org/EXTMETAP/Resources/COED-AlgeriaCP.pdf.

1 Corresponding author: Salah Eddine Sari Hassoun, Faculty Abou Bekr Belkaid of Economics, Business, and Management science, POLDEVA Laboratory, University of Tlemcen, Algeria. E-mail : salah.poldeva08@gmail.com

2 Mohammed Mékidiche (Lecturer A), Faculty of Economics and Commerce, University of Tlemcen, -Maghnia Annex-, Algeria. E-mail: mkidiche@yahoo.fr

3 Mohammed Seghir Guellil (Assistant-lecturer), Faculty of Economics and Commerce, University of Mascara, MCLDL Laboratory, Algeria. E-mail: Guellil.poldeva@gmail.com

To cite this article: Sari Hassoun, S. E., \& Mékidiche, M., \& Guellil, M. S. (2018). Examining the connection amongst renewable energy, economic growth and carbon dioxide emissions in Algeria. Ekoist: Journal of Econometrics and Statistics, 14(29), $199-223$.

https://doi.org/10.26650/ekoist.2018.14.29.0013 


\section{Introduction}

In 1999, the cost of environment degradation has been estimated at $3.6 \%$ of the Algerian GDP and it is estimated at 97 billion Algerian Dinars annually (1.7 billion US dollars) which was lost due to ecological issues, and the damage cost to the global environment was approximately $1.2 \%$ of the GDP.

The impact of soil degradation was evaluated on the basis of losses in agricultural productivity resulting from water and wind erosion. Water erosion threatens 12 million hectares (ha) in northern and western Algeria. Wind erosion threatens more than 7 million ha of arid and semi-arid land.

The urban air pollution was caused by the transport sector in the large cities of Algiers, Oran and Constantine by burning municipal waste (Oued Smar in Algiers, Oran), and by the big industries in Annaba, Skikda, and Gazaouet. Such pollution has triggered on a yearly basis 353,000 cases of bronchitis, 544,000 asthma attacks and could be the cause of the 1,500 cases of lung cancer.

The lack of potable water and sanitation as well as poor water quality and hygienic practices causes mortality in children under the age of 5, because of acute diarrheal diseases. It is estimated that 205,500 DALYs (Disability Adjusted Life Years) to be lost per year. In addition to the health impacts, limited consideration was given to water resource degradation due to dam silting which is estimated at $0.09 \%$ of the GDP.

Coastal degradation is due primarily to coastal erosion affecting 250-300 kilometres of beaches, sand extraction of 10 million cubic meters over the last 10 years, dredging a volume of 20 million cubic meters of soil from 18 ports, and over-exploitation of fisheries by increasing catches from 91,000 tons to 113,000 tons over the last decade. Estimates of coastal degradation were made on the basis of the loss of tourism revenues.

Consequently, the country made new national programs for renewable energy and energy efficiency which focus on the reduction of the greenhouse gas emissions and environmental problems ${ }^{1}$ by $7 \%$ to $22 \%$ in 2030 , compared to a business as usual -BAU- scenario, conditional on external support in terms of finance, technology development and transfer, and capacity building.

In the light on this statement, we shall study the effect of renewable energy and economic growth on the carbon dioxide emissions in Algeria during the period of 1995-2016. The objective is to study the impact of renewable energy consumption and the development of economic growth on reduction of carbon dioxide emissions. This paper is divided into 5 titles, the introduction, a literature review, data and methodology, empirical results and the conclusion.

1 United Nations for Climate Change (UNFCCC), (September 3 $\left.3^{\text {rd }}, 2015\right)$, «Intended nationally determined contribution INDC-Algeria». 


\section{Literature Review}

\section{The following table describes several studies in this domain:}

Table 1

Literature review about the relationship between $G D P, \mathrm{CO}_{2}$ emissions and renewable energy

\begin{tabular}{|c|c|c|c|c|}
\hline Study & Period & Data & Methodology & Conclusion \\
\hline $\begin{array}{l}\text { Inglesi- } \\
\text { Lotz and } \\
\text { Dogan } \\
(\mathbf{2 0 1 8})\end{array}$ & $\begin{array}{c}1980 \\
- \\
2011\end{array}$ & $\begin{array}{l}10 \text { biggest } \\
\text { electricity } \\
\text { generators in } \\
\text { Sub-Saharan } \\
\text { Africa } \\
\text { countries }\end{array}$ & DOLS & $\begin{array}{l}\text { The GDP and electricity production from } \\
\text { renewable source had a negative and significant } \\
\text { impact on carbon dioxide emissions, but the GDP } \\
\text { squared and electricity production from non- } \\
\text { renewable source had a positive and significant } \\
\text { impact on carbon dioxide emissions. }\end{array}$ \\
\hline $\begin{array}{l}\text { Apergis et } \\
\text { al. (2018) }\end{array}$ & $\begin{array}{c}1995 \\
- \\
2011\end{array}$ & $\begin{array}{l}42 \text { sub- } \\
\text { Saharan } \\
\text { Africa } \\
\text { countries }\end{array}$ & $\begin{array}{l}\text { DOLS and } \\
\text { FMOLS }\end{array}$ & $\begin{array}{l}\text { The GDP had a positive and significant impact } \\
\text { on }\left(\mathrm{CO}_{2}\right) \text { emissions, while the renewable energy } \\
\text { consumption had a negative and significant effect } \\
\text { on }\left(\mathrm{CO}_{2}\right) \text { emissions. }\end{array}$ \\
\hline $\begin{array}{l}\text { Mbarek et } \\
\text { al. (2018) }\end{array}$ & $\begin{array}{c}1990 \\
- \\
2015\end{array}$ & Tunisia & VECM & $\begin{array}{c}\text { An increase by } 1 \% \text { in (GDP) can raise renewable } \\
\text { energy consumption, energy use and }\left(\mathrm{CO}_{2}\right) \\
\text { emissions by } 1.33 \%, 0.36 \% \text { and } 1.12 \% \text {, } \\
\text { respectively. Also, they provided that a } 1 \% \\
\text { increase in }\left(\mathrm{CO}_{2}\right) \text { decreases (GDP) by } 0.28 \% \text {, but } \\
\text { a } 1 \% \text { increase in renewable upsurge (GDP) by } \\
0.16 \% \text {. }\end{array}$ \\
\hline $\begin{array}{l}\text { Solarin et } \\
\text { al. (2017) }\end{array}$ & $\begin{array}{c}1965 \\
- \\
2013\end{array}$ & $\begin{array}{l}\text { India and } \\
\text { China }\end{array}$ & ARDL & $\begin{array}{l}\text { The GDP and urbanisation had a positive effect } \\
\text { on } \mathrm{CO}_{2} \text { emissions, while real GDP squared and } \\
\text { hydroelectricity consumption had a negative } \\
\text { influence on } \mathrm{CO}_{2} \text { emissions }\end{array}$ \\
\hline
\end{tabular}

\begin{tabular}{|c|c|c|c|}
\hline $\begin{array}{c}\text { Shahbaz } \\
\text { et al. } \\
(2017)\end{array}$ & $\begin{array}{c}1960 \\
- \\
2016\end{array}$ & USA & $\begin{array}{l}\text { ARDL and } \\
\text { VECM }\end{array}$ \\
\hline $\begin{array}{c}\text { Dogan } \\
\text { and Aslan } \\
(2017)\end{array}$ & $\begin{array}{c}1995 \\
- \\
2011\end{array}$ & $\begin{array}{c}25 \text { European } \\
\text { countries }\end{array}$ & $\begin{array}{c}\text { LM bootstrap } \\
\text { panel } \\
\text { cointegration } \\
\text { test }\end{array}$ \\
\hline $\begin{array}{l}\text { Zoundi } \\
\text { (2017) }\end{array}$ & $\begin{array}{c}1980 \\
- \\
2012\end{array}$ & 25 countries & $\begin{array}{c}\text { DOLS, GMM, } \\
\text { dynamic fixed } \\
\text { effect, mean } \\
\text { group and } \\
\text { pooled mean } \\
\text { group. }\end{array}$ \\
\hline
\end{tabular}

The biomass energy consumption has a negative impact on $\mathrm{CO}_{2}$ emissions; GDP and GDP squared have a positive and negative effect, respectively on $\mathrm{CO}_{2}$ emissions

the elasticity of carbon emissions with respect to economic growth is negative and is reaching from $-0.10 \%$ to $-0.20 \%$, so this can lead to lower level of emissions

An increase by $1 \%$ in the consumption of renewable energy reduces $\left(\mathrm{CO}_{2}\right)$ emissions by $0.13 \%$, an increase by $1 \%$ in primary energy consumption can lead to increase $\left(\mathrm{CO}_{2}\right)$ emissions by $0.85 \%$, suggesting that the consumption of renewable energy along with primary energy reduces air quality by around $0.72 \%(0.85-0.13)$

a $1 \%$ increase in (GDP) increases $\left(\mathrm{CO}_{2}\right)$ emissions by 0.19 in the long-term and by $0.015 \%$ in short-term, while, an increase by $1 \%$

Panel

\begin{tabular}{|c|c|c|}
\hline $\begin{array}{l}\text { Attiaoui et } \\
\text { al. (2017) }\end{array}$ & $\begin{array}{c}1990 \\
- \\
2011\end{array}$ & $\begin{array}{c}22 \text { African } \\
\text { countries }\end{array}$ \\
\hline
\end{tabular}
in non-renewable energy consumption increases

$\left(\mathrm{CO}_{2}\right)$ emissions by $0.23 \%$ in the long-term and by $0.35 \%$ in the short-term. However, a $1 \%$ increase in renewable energy consumption decreases $\left(\mathrm{CO}_{2}\right)$ emissions by $0.22 \%$ in the longterm and by $0.07 \%$ in the short-term. 


\begin{tabular}{|c|c|}
\hline $\begin{array}{c}\text { Paramati } \\
\text { et al. } \\
(2017)\end{array}$ & $\begin{array}{c}1990 \\
- \\
2012\end{array}$ \\
\hline
\end{tabular}

\begin{tabular}{|c|c|c|c|}
\hline Ch & 1993 & 188 countri & Panel \\
\hline al. (20 & 2010 & 188 countries & $\begin{array}{c}\text { cointegration } \\
\text { and VECM }\end{array}$ \\
\hline
\end{tabular}

$\begin{array}{cccc}\begin{array}{c}\text { Al-Mulali } \\ \text { et al. }\end{array} & 1980 & \begin{array}{c}\text { Seven } \\ \text { selected }\end{array} & \begin{array}{c}\text { DOLS and } \\ \text { VECM }\end{array} \\ \mathbf{( 2 0 1 6 )} & 2010 & \text { regions } & \end{array}$

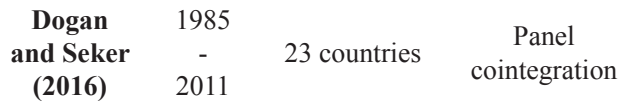

$\begin{array}{cccc}\begin{array}{c}\text { Sulaiman } \\ \text { et al. }\end{array} & 1980 & & \\ \text { (2013) } & 2009 & \text { Malaysia } & \text { ARDL }\end{array}$

\begin{tabular}{|c|c|c|c|}
\hline Menyah & & & The \\
\hline and & & ISA & generalized \\
\hline $\begin{array}{l}\text { Rufael } \\
(2010)\end{array}$ & 2007 & USA & $\begin{array}{l}\text { Iorecast error } \\
\text { variance } \\
\text { decomposition }\end{array}$ \\
\hline
\end{tabular}

The renewable energy consumption and income had a negative and significant impact on $\left(\mathrm{CO}_{2}\right)$ emissions

The energy consumption per capita has significant influences on $\left(\mathrm{CO}_{2}\right)$ emissions, a $1 \%$ increase in energy consumption per capita increase the emission of $\left(\mathrm{CO}_{2}\right)$ per capita by $7.6 \%, 26.1 \%$, and $13.5 \%$ in developed countries, developing countries, and in the world, respectively. However, the real (GDP) per capita contributes positively to the energy consumption per capita for both countries. However, in the long-run, an increase in energy consumption will decrease the rate of (GDP) in the world.

The GDP and GDP squared had a positive and negative impact, respectively on $\mathrm{CO}_{2}$ emissions except for the Sub Saharan Africa, and the renewable energy consumption had a negative influence on $\mathrm{CO}_{2}$ emissions except for the Sub

$$
\text { Saharan Africa, }
$$

the environmental effects of energy consumption by sources can allow an increases in renewable energy consumption by ( $1 \%)$ which will lead to mitigate the carbon emissions by $(3 \%$ or $4 \%$ ) and an increases in non-renewable energy consumption may rise the level of $\left(\mathrm{CO}_{2}\right)$ emissions by $(20 \%$ or $24 \%)$.

The elasticity of $\left(\mathrm{CO}_{2}\right)$ emissions with respect to electricity production from renewable sources was negative and statistically significant in both short and long-run.

The renewable energy consumption explains more than $19 \%$ of the forecast error variance of $\mathrm{CO}_{2}$ emissions and GDP explains not more than $7 \%$ of the forecast error variance of $\mathrm{CO}_{2}$ emissions.

Source: Done by the researchers

The $2^{\text {nd }}$ table defines several causalities in some literature review:

Table 2

Causality amongst GDP, $\mathrm{CO}_{2}$ emissions and renewable energy

\begin{tabular}{|c|c|c|c|}
\hline Study & Method & EKC & Causal relationship \\
\hline $\begin{array}{l}\text { Inglesi-Lotz and } \\
\text { Dogan (2018) }\end{array}$ & $\begin{array}{l}\text { Emirmahmutoglu-Kose } \\
\text { causality }\end{array}$ & No & 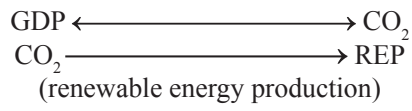 \\
\hline Apergis et al. (2018) & Granger causality & $\mathrm{N} / \mathrm{A}$ & $\begin{array}{l}\mathrm{RE} \longleftrightarrow \mathrm{CO}_{2} \\
\mathrm{GDP} \longrightarrow \mathrm{CO}_{2}\end{array}$ \\
\hline Mbarek et al. (2018) & Granger causality & N/A & $\begin{array}{l}\mathrm{CO}_{2} \longleftrightarrow \mathrm{GDP} \\
\mathrm{GDP} \longrightarrow \mathrm{RE}\end{array}$ \\
\hline
\end{tabular}


Solarin et al. (2017)

Granger causality

Shahbaz et al. (2017)

Dogan and Aslan

(2017)

Paramati et al. (2017)

Al-Mulali et al.

(2016)

Sulaiman et al.

(2013)

Menyah and Rufael

(2010)
Granger causality

Emirmah mutoglu-Kose procedure causality

Homogenous causality of Dumistrescu-Hurlin (2012)

VECM Granger causality

Granger causality

Toda-Yamamoto causality

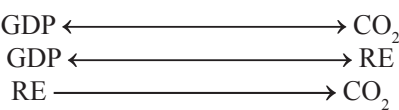

Biomass energy

Yes

Yes

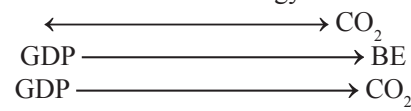

$\mathrm{GDP} \longleftrightarrow \mathrm{CO}_{2}$

N/A

Yes

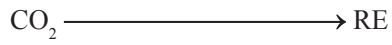

Several causalities between GDP, $\mathrm{CO}_{2}$ and RE.

N/A

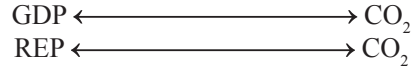

$\mathrm{GDP} \longleftrightarrow \mathrm{CO}_{2}$

N/A

$\mathrm{GDP} \longrightarrow \mathrm{RE}$

$\mathrm{CO}_{2} \longrightarrow \mathrm{RE}$

Source: Done by the researchers.

$\longleftrightarrow$ : Bidirectional causality

$\rightarrow$ : One-way causality

Therefore, these studies used different methodologies and variables to examine the link amongst renewable energy, economic growth and carbon dioxide emissions in several countries. The most variables used were trade openness, income (real GDP), GDP squared, $\mathrm{CO}_{2}$ emissions, electricity production and consumption from renewable and non-renewable sources, renewable energy consumption (in all forms), gross fixed capital formation, and labour force.

Some investigations demonstrate that most African countries still do not mainly depend on renewable energy in their energy production Attiaoui et al. (2017). However, according to World Bank ${ }^{2}$ and IEA ${ }^{3}$, the renewable energy will not only represent a decent addition to the total energy supply, but it will substitute the conventional fossil-fuelled energy as well. Also, the greener energy will allow meeting households' needs for energy and contribute to the improvement of air quality, but more efforts should be made to spread renewable energy policies across Africa and efforts should be made by households to switch to this new technology Zoundi (2017).

2 https://www.worldbank.org/

3 International Energy Agency. https://www.iea.org/ 


\section{Data and Methodology}

The following table displays all variables used in this study over the period of 1995-2016 in Algeria:

Table 3

Variables description

\begin{tabular}{lcc}
\hline Variables & Unites & Source of Data \\
\hline FEC : Fossil energy consumption & $\begin{array}{c}\text { Million tonne equivalent of } \\
\text { petrol (Mtep) }\end{array}$ & $\begin{array}{c}\text { Bp (British Petroleum) and } \\
\text { International Energy Agency (IEA) }\end{array}$ \\
FEP: Fossil energy production & Mtep & Bp and IEA \\
REC: Renewable energy consumption & Mtep & Bp \\
REP: Renewable energy production & Mtep & OECD \\
$\mathrm{CO}_{2}:$ Dioxide carbon emission & Million tonne carbon & Bp \\
GDP: Gross domestic product & dioxide & World Bank \\
GDP2: Gross domestic product square & Current US \$ & Current US \$ \\
Kyoto: Kyoto protocol & Dummy variable & In 1997 and in 2005 \\
Paris: Paris Agreement & Dummy variable & In 2015 \\
\hline Source: made by the researchers & & \\
\hline
\end{tabular}

The defined model is derivative from several literatures like Inglesi-Lotz and Dogan (2018), Apergis et al. (2018) and Mbarek et al. (2018)...etc. We shall use the variables of per capita $\mathrm{CO}_{2}$ emissions, per capita GDP and per capita REC in linear form, because it gives us consistent and efficient empirical results.

Also, the majority of the researchers and literatures in this domain follow a quadratic model with the inclusion of $\mathrm{GDP}^{2}$ variable to verify the validity of the Environment Kuznets Curve hypothesis.

$$
\begin{aligned}
& G D P_{t}=a_{1}+\sum_{i=1}^{p} b_{1 i} G D P_{t-1}+\sum_{i=1}^{p} c_{1 i} C O 2_{t-1}+\sum_{i=1}^{p} d_{1 i} R E C_{t-1}+e_{1} R V G D P^{2}{ }_{t}+f_{1} R V R E P_{t} \\
& +g_{1} \text { RVFEP }_{t}+h_{1} \text { RVFEC }_{t}+j_{1} \text { Kyoto }_{t}+k_{1} \text { Paris }_{t}+\varepsilon_{t 1} \\
& C O 2_{t}=a_{2}+\sum_{i=1}^{p} b_{2 i} G D P_{t-1}+\sum_{i=1}^{p} c_{2 i} C O 2_{t-1}+\sum_{i=1}^{p} d_{2 i} R E C_{t-1}+e_{2} R V G D P^{2}{ }_{t}+f_{2} R V R E P_{t} \\
& +g_{2} \text { RVFEP }_{t}+h_{2} \text { RVFEC }_{t}+j_{2} \text { Kyoto }_{t}+k_{2} \text { Paris }_{t}+\varepsilon_{t 2} \\
& R E C_{t}=a_{3}+\sum_{i=1}^{p} b_{3 i} G D P_{t-1}+\sum_{i=1}^{p} c_{3 i} C O 2_{t-1}+\sum_{i=1}^{p} d_{3 i} R E C_{t-1}+e_{3} R V G D P^{2}{ }_{t}+f_{3} R V R E P_{t} \\
& +g_{3} \text { RVFEP }_{t}+h_{3} \text { RVFEC }_{t}+j_{3} \text { Kyoto }_{t}+k_{3} \text { Paris }_{t}+\varepsilon_{t 3}
\end{aligned}
$$


GDP: represents the economic variable in Algeria that designs the economic growth or the economic factor of sustainable development because it takes into consideration the population over time $(\mathrm{t})$.

$\mathrm{CO}_{2}$ : indicates the level of dioxide carbon emissions and it represents the factors of pollution which is emitted by from industrial sector and fossil fuel energy.

REC: designs the variable of renewable energy consumption in Algeria, especially the consumption of solar photovoltaic, hydropower and geothermal over time ( $\mathrm{t}$ ).

$a_{1}, a_{2}$ and $a_{3}$ : are the intercept of each equation and they define the variables that are not included in the equation system like number of cars, fuel consumption and level of technology introduced which can have an influence on dioxide carbon...etc.

RVGDP $^{2}$ : Is gross domestic production square or income square. This variable is used to show the difference in the partial effect of real production on carbon emission and to verify the validity of the Environment Kuznets Curve hypothesis.

RVREP and RVFEP: are the realized volatility of fossil energy production and the renewable energy production. Both variables have a close relationship with the increase or the decrease of the carbon emission

FEC: is the $1^{\text {st }}$ control variable and it characterizes the realized volatility of fossil energy consumption in Algeria over time ( $\mathrm{t}$ ). There are many studies that stated that there is a close relationship between this variables and GDP, as it represents the main energy for the industrial development and technological advancement.

Kyoto and Paris: are the dummy variables that represent the Summit of Kyoto in 1997and in 2005, while the Paris climate conference was in 2015.

$\varepsilon_{\mathrm{t} 1}, \varepsilon_{\mathrm{t} 2}$ and $\varepsilon_{\mathrm{t} 3}$ : define the error term in the equation system and it represents also the innovation or the shock term that can be used to study the impulse responses.

The new evidence in such model is that we transformed the control variable into realized volatile series as they can be interpreted as variation change or rated coefficients. Then, in the time-series models, we usually employ the unit root procedure and cointegration test, to verify if such series can be estimated with Vector Autoregressive model (VAR), Vector Error Correction model (VECM), or Autoregressive Distributed Lags (ARDL) model...etc. And after, we select the perfect model.

Therefore, we tested the unit root with Phillips-Perron and Augmented DickeyFuller, so we make two hypotheses as following:

$\mathrm{H}_{0}$ (null hypothesis): the series has a unit root;

$\mathrm{H}_{1}$ (alternative hypothesis): the series has not a unit root;

Therefore, we make these two tests on 3 models: $\varepsilon_{\mathrm{t} 1}, \varepsilon_{\mathrm{t} 2}$ and $\varepsilon_{\mathrm{t} 3}$ 


$$
\begin{aligned}
& \Delta x_{t}=\partial x_{t-1}-\sum_{j=2}^{p} \omega_{j} \Delta x_{t-j+1}+\varepsilon_{t} \\
& \Delta x_{t}=\partial x_{t-1}-\sum_{j=2}^{p} \omega_{j} \Delta x_{t-j+1}+c+\varepsilon_{t} \ldots \ldots \ldots \ldots \ldots \ldots \text { (2); } \\
& \Delta x_{t}=\partial x_{t-1}-\sum_{j=2}^{p} \omega_{j} \Delta x_{t-j+1}+c+b * \text { trend }+\varepsilon_{t}
\end{aligned}
$$

In this study, we selected four lag $(\mathrm{p}=4)$ for the Schwarz Info Criterion, Bartlett Kernel as the spectral estimation method and the Newey-West Bandwidth.

We found that the three variables were stationary at $1^{\text {st }}$ difference, so they have the same order of integration I (1). Then, we need to check the optimal lag with lag length criteria with VAR estimation. Therefore, we concluded that the optimal model is with three lag $(\mathrm{p}=3)$, so we take $(\mathrm{p}=2)$ for Johansen cointegration test in Eviews 9.

Therefore, we concluded for the existence of VECM (2) model in 3 cointegration specifications (the model without interception, the model with interception in the long-run and the model with interception in the long and short-run). However, we selected the $2^{\text {nd }}$ model with only interception in the long-run, because it has the less value of Akaike and Schwarz criteria. Granger (1988) posited that the VECM is more suitable to investigate the causality between series that are integrated at I (1), thus the model is based on the assumption that all the variables are not exogenous and also premised on the fact that the depend variables are explained by the past values of the independent variables and the past values of the dependent variables.

However, the sign of long-run relationship was accepted, but not for all coefficients, so we need to check the validity of the coefficient with exogeneity test and to make some restriction in VECM.

$\mathrm{H}_{0}$ : the restricted coefficients equal to 0 ;

$\mathrm{H}_{1}$ : the restricted coefficients are unequal to 0 .

We struggled to find the perfect restriction for this VECM, but we selected the restriction $\mathrm{A}(2,2)=0, \mathrm{~A}(3,1)=0$ and we accepted in this case the null hypothesis, so the $2^{\text {nd }}$ coefficient of per capita GDP and the $1^{\text {st }}$ coefficient of per capita REC have a low power of exogeneity in this model.

We shall also study the impulse response and the variance decomposition between the innovation and shock (residual series) of each variable and verify the Granger causality between variables, the existence of long-run relationship doesn't mean that there is a real causality between variables, so we need to check if there is a two-way causality or one-way causality or there is no causality. 


\section{Empirical Results and Discussion}

\subsection{The coefficient diagnostic}

The system VECM equation have significant coefficients, the DGDP model have the regression coefficient equal to 0.94 , indicating that $94 \%$ of exogenous variables explain the endogenous variable and $6 \%$ were explicated by other factor that are not determining in the model, while the $\mathrm{DCO}_{2 \mathrm{t}}$ model have the regression coefficient equal to 0.99 , indicating that $99 \%$ of exogenous variables explain the endogenous variable and $1 \%$ were explicated by other factor that are not defining in the model, and the $\mathrm{DREC}_{\mathrm{t}}$ have the regression coefficient equal to 0.892 , indicating that $89.2 \%$ of exogenous variables explain the endogenous variable and $10.8 \%$ were explicated by other factor that are not determining in the model.

We can say also that the model was globally significant due to the high value of Fisher statistic.

\subsection{The residual diagnostic}

We initiated the investigations with the graph of the inverse roots of the characteristic AR polynomial (Lütkepohl, 1991). The autoregressive root graph showed that the model VAR is more or less stationary or stable.

We also tested with multivariate normality, if the residuals are normally distributed or not. Our outcomes showed that the VAR residuals are normally distributed and we concluded for the acceptation of the null hypothesis (normality distribution) and the rejection of alternative hypothesis.

\subsection{Discussion}

The model has 4 long-run coefficients, three of them have the negative sign and were statistically accepted, so we can accept the specification of VECM (2) restricted system equation.

In the $1^{\text {st }}$ equation when per capita GDP was considered as endogenous variable. The signs of DGDP ${ }_{t-1}$ and DGDP $_{t-2}$ were negative and significant at level of $5 \%$, respectively, so an increase by $1 \%$ in $\mathrm{DGDP}_{\mathrm{t}-1}$ and $\mathrm{DGDP}_{\mathrm{t}-2}$ will decrease the economic growth by $1.392 \%$ and $0.756 \%$, respectively, confirming the result of previous models (economic growth-renewable energy consumption model), so we can say that the industrial and the economic development of the country is lesser than what it was in the previous periods.

The sign of $\mathrm{DCO}_{2 \mathrm{t}-1}$ was positive and significant at level of $5 \%$, and $\mathrm{DCO}_{2 \mathrm{t}-2}$ was negative and insignificant, demonstrating that a rise by $1 \%$ in carbon dioxide emission in 2015 had a positive impact on GDP by $5.27 * 10^{9} \%$, so this result indicates 
that the country depends on a lot on goods and services that emitted the polluted air to develop its economic growth.

The coefficient of $\mathrm{DREC}_{\mathrm{t}-1}$ and $\mathrm{DREC}_{\mathrm{t}-2}$ were negative and insignificant, so this result is in line with the main hypothesis of Growth, indicating that Algeria did not depend on renewable energy to improve its socio-economic situation.

The variables of realized volatility of fossil energy production and consumption have a statistically accepted negative and positive coefficient, respectively, so an increase by 1 unit in RVFEP and RVFEP will decrease and increase the variation level of GDP by -305048.6 and by 754208.4, respectively. Therefore, we found an unexpected result, because Algeria is considered as one of the country that rely on fossil energy production, so this might reveal the existence of inefficiency in energy production and it may contribute negatively to the economic growth, while the sign of fossil energy consumption was good and have positive affect on per capita GDP.

The sign of RVREP, RVGDP ${ }^{2}$ and Kyoto were both positive and insignificant, so they do not have any effect on GDP, while the coefficient of Paris was negative and statistically accepted, indicating that this conference had a negative effect on GDP of Algeria. in these circumstances when the country tries to change, systematically and rapidly its energy policy, it will impact negatively its economic growth (the change from fossil fuel dependence towards renewable energy dependence and then diminish the deforestation, loss of biodiversity, the carbon emissions and other sources of greenhouse gas were the aims of the Paris Summit).

In the $2^{\text {nd }}$ equation when per capita $\mathrm{CO}_{2}$ was considered as endogenous variable. The sign of DGDP $\mathrm{t}_{\mathrm{t}-1}$ and $\mathrm{DGDP}_{\mathrm{t}-2}$ were positive, and significant at level of $1 \%$ and $5 \%$, respectively, so an increase by $1 \%$ in $\mathrm{DGDP}_{\mathrm{t}-1}$ and $\mathrm{DGDP}_{\mathrm{t}-2}$ will upsurge the rate of carbon dioxide emissions by $2 * 10^{-100} \%$ and $4.05^{*} 10^{-11} \%$, indicating that the industrial and the economic development of the country is depending a lot of polluted goods and services, so confirming again the relationship between GDP, $\mathrm{CO}_{2}$ and fossil energy. This result is supported by the studies of Mbarek et al. (2018), Apergis et al. (2018) and Attiaoui et al. (2017).

The sign of $\mathrm{DCO}_{2 \mathrm{t}-1}$ was positive and insignificant, while the coefficient $\mathrm{DCO}_{2 \mathrm{t}-2}$ was statistically positive, demonstrating that a rise by $1 \%$ in carbon dioxide emission in 2014 had a positive impact on itself by $0.258 \%$, approving the last result.

The coefficient of DREC ${ }_{\mathrm{t}-1}$ and $\mathrm{DREC}_{\mathrm{t}-2}$ were negative, insignificant and significant, respectively, so an increase by $1 \%$ in renewable energy consumption in 2014 would diminish the level of carbon dioxide emission by $18.50 \%$. Consequently, the renewable energy can reduce the pollution factor that causes the warm climate. Also, Algeria is going to apply an energy policy that focuses on photovoltaic and wind energy, as they represent the alternative of hydropower and biomass energy which 
emit a lot of negative gas from their chemical product that contaminate the ocean and increase deforestation and the loss of biodiversity. This result is in line with the main literature of Inglesi-Lotz and Dogan (2018), Zoundi (2017), Paramati et al. (2017), Dogan and Seker (2016) and Sulaiman et al. (2013).

The variables of RVFEP and RVFEC have a positive and significant coefficient, respectively, so an increase by 1 unit in RVFEP and RVFEP will surge the variation level of carbon dioxide emissions by $3.35^{*} 10^{-5}$ and by $4.40^{*} 10^{-5}$, respectively. This outcome is in line with the hypothesis that the country is depending on fossil energy which represent the main source of energy that emits a lot of pollution in the atmosphere, carbon dioxide especially. This result indicates also that the country in this period was using unclean technology that used the waste and combustible energy which emits a high level of pollution in the ecosystem. Consequently, the energy policy of Algeria for now appears to be more focused on supporting the development of its economic growth than encouraging the decline of the air pollution. The same result found in studies of Inglesi-Lotz and Dogan (2018), Attiaoui et al. (2017), and Chen et al. (2016).

For the rest of variables in this equation, they had an insignificant coefficient, meaning that Algeria was not concerned by the objectives of such conferences such as the protection of the fish stocks, the introduction of sustainable development term to the private sector and in global companies.

Also, we could not accept the Environment Kuznets Curves Hypothesis where the level of ecological pollution initially rise with income until it attains its equilibrium points, because the RVGDP² was not significant, so the EKC hypothesis is not valid, in this situation and we can say that the country is considered as a developing country that needs a lot of polluted manufactures and productions to keep its economic growth expansion and to develop its economic structure. This result is supported by studies of Inglesi-Lotz and Dogan (2018), Zoundi (2017) and Dogan and Ozturk (2017).

In the $3^{\text {rd }}$ equation when per capita REC was considered as endogenous variable. All variables seem to be insignificant in every level, except the Kyoto variable, so an increase by 1 unit in the dummy variable of Kyoto will surge the elasticity of renewable energy consumption by $1.93 * 10^{-9}$, showing that the country is starting to more concerned with the environmental issues and Algeria is aware of the ratification of the Kyoto protocol and it will have a good consequence on the adoption of renewable sources.

After analyzing the impact of each coefficient on the VECM system, we shall display the impulse response to indicate the variation between the endogenous variables and their residual series. In the $1^{\text {st }}$ period, a shock on per capita $\mathrm{CO}_{2}$ does not have a contemporary effect on per capita GDP or on per capita REC, confirming the result of causality, while a shock on GDP has a contemporary effect on $\mathrm{CO}_{2}$ only. The shock or innovation amplitude of GDP was 233.657 and 
will immediately be reflecting on $\mathrm{CO}_{2}$ shock by $4.11 * 10^{-9}$, confirming the positive relationship between GDP and $\mathrm{CO}_{2}$. Also, a shock on REC has a contemporary effect on $\mathrm{CO}_{2}$ and GDP, by $6.69 * 10^{-10}$ and it will directly be reflecting on GDP innovation by 128.77 and on $\mathrm{CO}_{2}$ shock by $1.39 * 10^{-8}$, confirming the positive link among REC and GDP, and a negative relationship between REC and CO2, suggesting that in the $1^{\text {st }}$ period Algeria was using combustible renewables that release a lot of carbon dioxide in the air. In the $2^{\text {nd }}$ period, a shock on $\mathrm{CO}_{2}$ by $2.44 * 10^{-9}$ has contemporary effect on innovation of GDP by 7.979 and on innovation of REC by $3.86^{*} 10^{-12}$. A shock on GDP by $-70.809{ }^{9}$ has a current impact on shock of $\mathrm{CO}_{2}$ by $3.86^{*} 10^{-8}$ and on the innovation of REC by $5.41 * 10^{-11}$, while an innovation on REC by $9.68 * 10^{-11}$ will influence the innovation of $\mathrm{CO}_{2}$ by $3.38^{*} 10^{-8}$ and the shock of GDP by 214.073. From this outcome, we can say that Algeria is focusing on development of economic growth rather than reducing environmental issues, so the country is not concerned with the international conferences on climate change (the protocol Kyoto and the Summit of Paris).

The variance decomposition indicates in the $3^{\text {rd }}$ period, that the forecast errors of per capita $\mathrm{CO}_{2}$ is due $0.581 \%$ of its innovation, $29.069 \%$ of per capita GDP innovation, and $70.35 \%$ of per capita REC shock, while the forecast errors of GDP is due to $67.078 \%$ of its shock, $0.026 \%$ to per capita $\mathrm{CO}_{2}$ innovation and $32.896 \%$ to per capita REC innovation. And, the forecast errors of REC is due to $99.062 \%$ to its shock, while $0.927 \%$ to $\mathrm{CO}_{2}$ innovation and $0.011 \%$ of GDP innovation. Consequently, this result confirms the Granger causality test.

\subsection{Granger causality}

Table 4

VEC Granger causality/Block exogeneity between $\mathrm{DGDP}, \mathrm{DCO} \mathrm{O}_{2}$ and $\mathrm{DREC}$

\begin{tabular}{lcc}
\hline & DGDP & \\
\hline Excluded & Chi-square & Probability \\
DCO $_{2 \mathrm{t}}$ & $9.302^{*}$ & 0.009 \\
$\mathrm{DREC}_{\mathrm{t}}$ & 3.170 & 0.204 \\
\hline & DCO $_{2}$ & \\
\hline Excluded & Chi-square & Probability \\
DGDP $_{\mathrm{t}}$ & $100.401^{*}$ & 0 \\
DREC $_{\mathrm{t}}$ & $12.705^{*}$ & 0.001 \\
\hline & DREC & Probability \\
\hline Excluded & Chi-square & 0.857 \\
DGDP $_{\mathrm{t}}$ & 0.308 & 0.984 \\
\hline DCO $_{2 \mathrm{t}}$ & 0.031 &
\end{tabular}

Source: Done on EViews 9. 
Table 5

Granger causality between per capita $\mathrm{CO}_{2}, G D P$ and $\mathrm{REC}$ with $(p=2)$

\begin{tabular}{lcc}
\hline Null hypothesis & Fisher-statistic & Probability \\
\hline $\mathrm{CO}_{2}$ does not Granger cause GDP & 1.180 & 0.334 \\
GDP does not Granger cause $\mathrm{CO}_{2}$ & $12.149^{*}$ & 0 \\
REC does not Granger cause GDP & 1.636 & 0.227 \\
GDP does not Granger cause REC & 1.525 & 0.249 \\
$\mathrm{CO}_{2}$ does not Granger cause REC & 0.008 & 0.991 \\
REC does not Granger cause $\mathrm{CO}_{2}$ & 0.111 & 0.894 \\
\hline
\end{tabular}

Source: Done on EViews 9.

The Granger causality in the short-run revealed that there is bidirectional causality between per capita $\mathrm{DCO}_{2}$ and per capita DGDP at level of $1 \%$ and we also found that there is a unidirectional causality running from per capita DREC to per capita $\mathrm{DCO}_{2}$ at level of $1 \%$. Therefore, we can say that the carbon dioxide emissions and economic growth are interrelated to each other, so when there is a variation on GDP, it will impact directly the level of $\mathrm{CO}_{2}$, and it is the same when there is a change in $\mathrm{CO}_{2}$, it will influence the economic growth factor, confirming that Algeria depends a lot on combustible and fuel energy that emits a lot of polluted gas. The same result was found in the studies of Inglesi-Lotz and Dogan (2018), Mbarek et al. (2018), Solarin et al. (2017), Dogan and Aslan (2017), Sulaiman et al. (2013) and Menyah and Wolde-Rufael (2010), while an impact on REC has a direct effect on $\mathrm{CO} 2$, we saw that the consumption of renewable energy, especially the photovoltaic and wind energy can decrease the level of carbon dioxide emissions, we can add that renewable energy is considered clean energy power since renewables induce far fewer pollutant gas emissions when they are compared to fossil energy sources, such as petrol, coal and natural gas. This result is supported by the main literature of Solarin et al. (2017) and Al-Mulali et al. (2016). However, in the long-run there is a one-way causality running from per capita GDP to per capita $\mathrm{CO}_{2}$ and it confirms the previous findings. This result is in line with the investigations of Apergis et al. (2018), and Shahbaz et al. (2017).

\section{Conclusion}

We established that the variable of economic growth will increase the level of carbon dioxide, indicating that Algeria still depends on combustible and fossil fuel that release a lot of carbon in the atmosphere and it approves the neutrality hypothesis between REC and GDP. However, we found that the use of renewable energy in Algeria can decrease the level of carbon dioxide emissions, and this result indicates the importance to include this source of energy in Algeria and its importance to mitigate issues related to the environment. We also found that there is no evidence for Environment Kuznets Curves hypothesis, because the country still depends on sources that emit a high quantity of pollution. 
Consequently, this study reveals that a rise in the Algerian economic and industrial production will reduce the emission of carbon dioxide for a short-term, while if the country diminishes its economic growth, it will positively affect the emission of carbon dioxide, so in this case Algeria needs some controlling strategies that should be applied to fight against environmental pollution which is produced by several institutions, firms, factories, and electricity power companies. Therefore, they should be forced by regulations to meet some portion of their energy needs from renewable sources, and to gradually increase its portion in the future.

\section{References}

Akaike, H. (1973). Information theory and an extension of the maximum likelihood principle, in B.N. Petrov and F. Csáki, eds, 2nd International Symposium on Information Theory, Akadémia Kiadó, Budapest, 267-281. https://hero.epa.gov/hero/index.cfm/reference/details/reference_id/591

Al-Mulali, U., Ozturk, I., \& Solarin, S.A. (2016). Investigating the environmental Kuznets curve hypothesis in seven regions: The role of renewable energy, Ecological Indicators, 67, 267-282. https://doi.org/10.1016/j.ecolind.2016.02.059

Apergis, N., Jebli, M.B., \& Youssef, S.B. (2018). Does Renewable Energy Consumption and Health Expenditures Decrease Carbon Dioxide Emissions? Evidence for sub-Saharan Africa Countries, Renewable Energy, 127, 1011-1016. https://doi.org/10.1016/j.renene.2018.05.043

Attiaoui, I., Toumi, H., Ammouri, B., \& Gargouri, I. (2017). Causality links among renewable energy consumption, $\mathrm{CO}_{2}$ emissions, and economic growth in Africa: evidence from a panel ARDL-PMG approach, Environmental Science and Pollution Research, 24 (14), 13036-13048. https://link.springer.com/article/10.1007\%2Fs11356-017-8850-7

Chen, P.Y., Chen, S.T., Hsu, C.S., \& Chen, C.C. (2016). Modeling the global relationships among economic growth, energy consumption and $\mathrm{CO}_{2}$ emissions, Renewable and Sustainable Energy Reviews, 65, 420-431. https://doi.org/10.1016/j.rser.2016.06.074

Dickey, D.A., \& Fuller, W.A. (1981). Likelihood ratio statistics for autoregressive time series with unit root, Econometrica, 49 (4), 1057-1072. https://www.jstor.org/stable/1912517?seq=1\#page_ scan_tab_contents

Dickey, D.A., \& Fuller, W.A. (1988). Testing for a Unit Root in Time Series Regression, Biometrika Trust, 75 (2), 335-346. http://finpko.faculty.ku.edu/myssi/FIN938/Phillips\%20\%26\%20Perron Biometrika_1988_Unit\%20Root\%20Test.pdf

Dogan, E., \& Aslan, A. (2017). Exploring the relationship among $\mathrm{CO}_{2}$ emissions, real GDP, energy consumption and tourism in the EU and candidate countries: Evidence from panel models robust to heterogeneity and cross-sectional dependence, Renewable and Sustainable Energy Reviews, 77, 239-245. https://doi.org/10.1016/j.rser.2017.03.111

Dogan, E., \& Ozturk, I. (2017). The influence of renewable and non-renewable energy consumption and real income on $\mathrm{CO}_{2}$ emissions in the USA: evidence from structural break tests, Environmental Science and Pollution Research, 24 (11), 10846-10854. https://link.springer. com/article/10.1007/s11356-017-8786-y

Dogan, E., \& Seker, F. (2016). The influence of real output, renewable and non-renewable energy, trade and financial development on carbon emissions in the top renewable energy countries, Renewable and Sustainable Energy Reviews, 60, 1074-1085. https://doi.org/10.1016/j. rser.2016.02.006 
Engle, R.F., \& Granger, C.W.J. (1987). Co-Integration and Error Correction: Representation, Estimation, and Testing, Econometrica, 55 (2), 251-276. http://www.ntuzov.com/Nik_Site/ Niks_files/Research/papers/stat_arb/EG_1987.pdf

Granger, C.W.J. (1969). Investigating Causal Relations by Econometrics Models and CrossSpectral Methods, Econometrica, 37 (3), 424-438. http://tyigit.bilkent.edu.tr/metrics2/read/ Investigating $\% 20 \% 20$ Causal $\% 20$ Relations $\% 20$ by $\% 20$ Econometric $\% 20$ Models $\% 20$ and $\% 20$ Cross-Spectral\%20Methods.pdf

Granger, C.W.J.(1988). Some recent development in a concept of causality, Journal of Econometrics, 39 (1-2), 199-211. https://doi.org/10.1016/0304-4076(88)90045-0

Hannan, E.J., \& Quinn, B.G. (1979). The Determination of the Order of an Autoregression, Journal of the Royal Statistical Society. Series B, 41 (2), 190-195. http://www.jstor.org/stable/2985032

Inglesi-Lotz, R., \& Dogan, E. (2018). The role of renewable versus non-renewable energy to the level of $\mathrm{CO}_{2}$ emissions a panel analysis of sub-Saharan Africa's Big 10 electricity generators, Renewable Energy, 123, 36-43. https://doi.org/10.1016/j.renene.2018.02.041

Johansen, S. (1988). Statistical analysis of cointegration vectors, Journal of Economic Dynamics and Control, 12 (2-3), 231-254. https://doi.org/10.1016/0165-1889(88)90041-3

Johansen, S. (1991). Estimation and Hypothesis Testing of Cointegration Vectors in Gaussian Vector Autoregressive Models, 59 (6), 1551-1580. http://www.jstor.org/stable/2938278

Lütkepohl, H. (1991). Introduction to Multiple Time Series Analysis, Springer Berlin Heidelberg New York. http://www.afriheritage.org/TTT/2\%20New\%20Introduction\%20to\%20 Multiple\%20Time\%20Series\%20Analysis.pdf

Mbarek, M.B., Saidi, K., \& Rahman, M.M. (2018). Renewable and non-renewable energy consumption, environmental degradation and economic growth in Tunisia, Quality \& Quantity, 52 (3), 1105-1119. https://link.springer.com/article/10.1007\%2Fs11135-017-0506-7

Menyah, K., \& Wolde-Rufael, Y. (2010). $\mathrm{CO}_{2}$ emissions, nuclear energy, renewable energy and economic growth in the US, Energy Policy, 38 (6), 2911-2915. https://doi.org/10.1016/j. enpol.2010.01.024

Paramati, S.R., Sinha, A., \& Dogan, E. (2017). The significance of renewable energy use for economic output and environmental protection: evidence from the Next 11 developing economies, Environmental Science and Pollution Research, 24 (15), 13546-13560. https://link. springer.com/article/10.1007/s11356-017-8985-6

Schwarz, G. (1978). Estimating the dimension of a model, The annals of Statistics, 6 (2), 461-464. http://qwone.com/ jason/trg/papers/schwarz-dimension-78.pdf

Shahbaz, M., Solarin, S.A., Hammoudeh, S., \& Shahzad, S.J.H. (2017). Bound testing approach to analyzing the environment Kuznets curve hypothesis with structural breaks: The role of biomass energy consumption in the United States, Energy Economics, 68, 548-565. https://doi. org/10.1016/j.eneco.2017.10.004

Solarin, S.A., Al-Mulali, U., \& Ozturk, I. (2017). Validating the environmental Kuznets curve hypothesis in India and China: The role of hydroelectricity consumption, Renewable and Sustainable Energy Reviews, 80, 1578-1587. https://doi.org/10.1016/j.rser.2017.07.028

Sulaiman, J., Azman, A., \& Saboori, B. (2013). The Potential of Renewable Energy: Using the Environmental Kuznets Curve Model, American Journal of Environmental Sciences, 9 (2), 103112. https://thescipub.com/pdf/10.3844/ajessp.2013.103.112

United Nations for Climate Change (UNFCCC), (September $\left.3^{\text {rd }}, 2015\right)$, « Intended nationally determined contribution INDC-Algeria». 
Zoundi, Z. (2017). CO2 emissions, renewable energy and the Environmental Kuznets Curve, a panel cointegration approach, Renewable and Sustainable Energy Reviews, 72, 1067-1075. https://linkinghub.elsevier.com/retrieve/pii/S1364032116306682

http://siteresources.worldbank.org/EXTMETAP/Resources/COED-AlgeriaCP.pdf

https://www.iea.org/

https://www.worldbank.org/ 


\section{Appendices}

\section{Appendix "A": Univariate study}

Table 6

Long memory test on per capita exogenous variables

\begin{tabular}{lccc}
\hline Variables & $\begin{array}{c}\text { "D" parameter of Robinson and } \\
\text { Henry }\end{array}$ & $\begin{array}{c}\text { "D" parameter of Geweke and } \\
\text { Porter-Hudak }\end{array}$ & Method \\
\hline FEC & $0.34^{*}$ & $0.47^{*}$ & ARFIMA \\
FEP & $0.35^{*}$ & 0.526 & ARFIMA/ARMA \\
GDP $^{2}$ & $0.00007^{*}$ & $0.00006^{*}$ & ARFIMA \\
REP & $0.29^{*}$ & $0.40^{*}$ & ARFIMA \\
\hline
\end{tabular}

Source: Done on the Ox-Metrics 6.0

*, indicate that we can reject the null hypothesis of short memory process rather we accept the alternative hypothesis of a long memory process, because the coefficient of " $d " \in(0,0.5)$. We verified these tests with OLS estimation on Eviews 9, if the sign of "d" was significant or not. However, we found that per capita GDP² cannot be performed with ARFIMA method, but with ARMA method.

Table 7

ARCH/GARCH or FIARCH/FIGARCH test

\begin{tabular}{l|c|c|c}
\hline \multicolumn{1}{c}{ Variables } & \multicolumn{1}{c}{ Model } & Fisher statistic & LR test $\left(\mathbf{N}^{*} \mathbf{R}^{2}\right)$ \\
\hline FEC & ARFIMA (2,d,2) & 0.01 & 0.01 \\
FEP & ARFIMA (0,d,0) & 0.44 & 0.44 \\
GDP $^{2}$ & ARMA (0,0) & 0.003 & 0.003 \\
REP & ARFIMA (3,d,2) & 0.01 & 0.01 \\
\hline
\end{tabular}

Source: Done on the EViews 9

*, demonstrate that we accept the alternative hypothesis of existence of ARCH effect, but in this case we accepted the null hypothesis, so there's no ARCH effect on exogenous variables and we shall estimate the realized volatility with this formula:

$$
\sigma=\sqrt{\frac{1}{T} \sum_{i=1}^{T}\left(r_{i}-\bar{r}\right)^{2}}
$$

$\sigma$ is the realized volatility of series and $r_{i}$ is the rated or yield series. 
Table 8

Unit root test of per capita GDP

\section{Per capita GDP}

\begin{tabular}{|c|c|c|c|c|c|c|}
\hline \multirow[b]{2}{*}{ Models } & \multicolumn{2}{|c|}{ Phillips-Perron } & \multicolumn{3}{|c|}{ Augmented Dickey-Fuller } & \multirow[b]{2}{*}{ Decision } \\
\hline & On level & $1^{\text {st }}$ difference & Models & On level & $1^{\text {st }}$ difference & \\
\hline Model 3 & -0.984 & $-3.952 * *$ & Model 3 & -0.984 & $-3.953 * *$ & $\mathrm{I}(1)$ \\
\hline Model 2 & -1.193 & $-3.909 * *$ & Model 2 & -1.193 & $-3.907 * * *$ & $\mathrm{I}(1)$ \\
\hline Model 1 & 0.355 & $-3.872 * * *$ & Model 1 & 0.355 & $-3.872 * * *$ & $\mathrm{I}(1)$ \\
\hline
\end{tabular}

Source: made on EViews 9.

Table 9

Unit root test of per capita REC

per capita REC

\begin{tabular}{lcclccc}
\hline \multicolumn{2}{c}{ Phillips-Perron } & \multicolumn{3}{c}{ Augmented Dickey-Fuller } \\
\hline Models & On level & $1^{\text {st }}$ difference & Models & On level & $1^{\text {st }}$ difference & Decision \\
Model 3 & $-3.803^{* *}$ & $-11.480 * * *$ & Model 3 & $-3.803 * *$ & $-6.474 * * *$ & $\mathrm{I}(1)$ \\
Model 2 & $-3.597 * *$ & $-11.233^{* * *}$ & Model 2 & $-3.597 * *$ & $-6.655^{* * *}$ & $\mathrm{I}(1)$ \\
Model 1 & -1.120 & $-10.725 * * *$ & Model 1 & $-1.362 * * *$ & $-6.837 * * *$ & $\mathrm{I}(1)$ \\
\hline
\end{tabular}

Source: made on EViews 9.

Table 10

Unit root test of per capita $\mathrm{CO}^{2}$

per capita $\mathrm{CO}_{2}$

\begin{tabular}{|c|c|c|c|c|c|c|}
\hline \multirow[b]{2}{*}{ Models } & \multicolumn{2}{|c|}{ Phillips-Perron } & \multicolumn{3}{|c|}{ Augmented Dickey-Fuller } & \multirow[b]{2}{*}{ Decision } \\
\hline & On level & $1^{\text {st }}$ difference & Models & On level & $1^{\text {st }}$ difference & \\
\hline Model 3 & $-5.021 * * *$ & $-3.297 *$ & Model 3 & -2.854 & $-3.609 *$ & $\mathrm{I}(1)$ \\
\hline Model 2 & 1.149 & $-3.118 * *$ & Model 2 & $\cdots$ & $-3.201 * *$ & $\mathrm{I}(1)$ \\
\hline Model 1 & 2.262 & $-2.590 * *$ & Model 1 & $\ldots$ & $-2.641 * *$ & $\mathrm{I}(1)$ \\
\hline
\end{tabular}

Source: made on EViews 9.

Table 11

Unit root test of $R V F E C$

\section{RVFEC}

\begin{tabular}{|c|c|c|c|c|c|c|}
\hline \multirow[b]{2}{*}{ Models } & \multicolumn{2}{|c|}{ Phillips-Perron } & \multicolumn{3}{|c|}{ Augmented Dickey-Fuller } & \multirow[b]{2}{*}{ Decision } \\
\hline & On level & $1^{\text {st }}$ difference & Models & On level & $1^{\text {st }}$ difference & \\
\hline Model 3 & -1.456 & $\ldots$ & Model 3 & -1.559 & $\ldots$ & $\mathrm{I}(0)$ \\
\hline Model 2 & -2.031 & $\ldots$ & Model 2 & -2.014 & $\ldots$ & $\mathrm{I}(0)$ \\
\hline Model 1 & $-2.298 * *$ & $\ldots$ & Model 1 & $-2.755 * * *$ & $\ldots$ & $\mathrm{I}(0)$ \\
\hline
\end{tabular}

Source: made on EViews 9. 
Table 12

Unit root test of $R V F E P$

\begin{tabular}{|c|c|c|c|c|c|c|c|}
\hline \multirow[b]{3}{*}{ Models } & \multicolumn{6}{|c|}{ RVFEP } & \multirow[b]{3}{*}{ Decision } \\
\hline & \multicolumn{3}{|c|}{ Phillips-Perron } & \multicolumn{3}{|c|}{ Augmented Dickey-Fuller } & \\
\hline & On level & $1^{\text {st }}$ & difference & Models & On level & $1^{\text {st }}$ difference & \\
\hline Model 3 & -2.508 & & $\ldots$ & Model 3 & -2.600 & $\ldots$ & $\mathrm{I}(0)$ \\
\hline Model 2 & $-2.748 *$ & & $\cdots$ & Model 2 & $-2.812 *$ & $\ldots$ & $\mathrm{I}(0)$ \\
\hline Model 1 & $-2.847 * * *$ & & $\ldots$ & Model 1 & $-2.882 * * *$ & $\ldots$ & $\mathrm{I}(0)$ \\
\hline
\end{tabular}

Source: made on EViews 9.

Table 13

Unit root test of RVREP

\begin{tabular}{lccccccc}
\hline \multicolumn{7}{c}{ RVREP } \\
\hline \multicolumn{7}{c}{ Phillips-Perron } & \multicolumn{7}{c}{ Augmented Dickey-Fuller } \\
\hline Models & On level & $1^{\text {st }}$ & difference & Models & On level & $1^{\text {st }}$ difference & Decision \\
Model 3 & $-3.560^{*}$ & $\ldots$ & Model 3 & $-3.697 * *$ & $\ldots$ & $\mathrm{I}(0)$ \\
Model 2 & $-3.645^{* *}$ & $\ldots$ & Model 2 & $-3.712^{* *}$ & $\ldots$ & $\mathrm{I}(0)$ \\
Model 1 & $-3.750^{* * *}$ & $\ldots$ & Model 1 & $-3.810^{* * *}$ & $\ldots$ & $\mathrm{I}(0)$ \\
\hline
\end{tabular}

Source: made on EViews 9.

Table 14

Unit root test of $R V G D P^{2}$

\begin{tabular}{|c|c|c|c|c|c|c|c|}
\hline \multicolumn{7}{|c|}{ RVGDP $^{2}$} & \multirow[b]{3}{*}{ Decision } \\
\hline & \multicolumn{3}{|c|}{ Phillips-Perron } & \multicolumn{3}{|c|}{ Augmented Dickey-Fuller } & \\
\hline Models & On level & $1^{\mathrm{st}}$ & difference & Models & On level & $1^{\text {st }}$ difference & \\
\hline Model 3 & $-4.640 * * *$ & & $\ldots$ & Model 3 & $-4.628 * * *$ & $\ldots$ & $\mathrm{I}(0)$ \\
\hline Model 2 & $-4.588 * * *$ & & $\ldots$ & Model 2 & $-4.587 * * *$ & $\ldots$ & $\mathrm{I}(0)$ \\
\hline Model 1 & $-4.706^{* * *}$ & & $\ldots$ & Model 1 & $-4.706 * * *$ & $\ldots$ & $\mathrm{I}(0)$ \\
\hline
\end{tabular}

Source: made on EViews 9.

$(* * *),(* *),(*)$ Show that the null hypothesis would be rejected respectively at $1 \%, 5 \%$ or $10 \%$, so there's no existence of unit root. However, the variables of HDI and $\mathrm{CO}_{2}$ have an insignificant trend, so we made the stationary series with differency stationary. But, the RVEU had a significant trend, so we avoided this deterministic trend and created RVEU without trend.

Table 15

The selection lag criterion

\begin{tabular}{|c|c|c|c|}
\hline Lag & AIC & SC & HQ \\
\hline 0 & -50.913 & -49.869 & -50.736 \\
\hline 1 & -55.018 & -53.527 & -54.765 \\
\hline 2 & -56.456 & -54.517 & -56.128 \\
\hline 3 & $-62.232 *$ & $-59.846^{*}$ & $-61.829 *$ \\
\hline
\end{tabular}

Source: made on EViews 9

*, indicate the optimal lag for the VAR model. 
Table 16

Johansen cointegration test

\begin{tabular}{lccc}
\hline \multicolumn{4}{c}{$\mathbf{1}^{\text {st }}$ model specification } \\
\hline Eigenvalue & Unrestricted cointegration rank test (Trace) & \\
\hline 0.845 & $\lambda$ trace statistic & $\mathbf{5 \%}$ critical value & Probability \\
0.433 & $46.285^{*}$ & 24.275 & 0 \\
0.001 & 10.825 & 12.320 & 0.087 \\
\hline
\end{tabular}

\begin{tabular}{lccc}
\hline \multicolumn{4}{c}{ Unrestricted cointegration rank test (Maximum Eigenvalue) } \\
\hline Eigenvalue & Max-Eigen statistic & $\mathbf{5 \%}$ critical value & Probability \\
\hline 0.845 & $35.459 *$ & 17.797 & 0 \\
0.433 & 10.802 & 11.224 & 0.059 \\
0.001 & 0.023 & 4.129 & 0.900 \\
\hline \multicolumn{4}{c}{$\mathbf{2}^{\text {nd }}$ model specification } \\
\hline Eigenvalue & Unrestricted cointegration rank test (Trace) \\
\hline 0.996 & $\lambda$ trace statistic & $\mathbf{5 \%}$ critical value & Probability \\
0.822 & $142.769^{*}$ & 35.192 & 0 \\
0.088 & $34.618^{*}$ & 20.261 & 0 \\
\hline
\end{tabular}

\begin{tabular}{lccc}
\hline \multicolumn{4}{c}{ Unrestricted cointegration rank test (Maximum Eigenvalue) } \\
\hline Eigenvalue & Max-Eigen statistic & $\mathbf{5 \%}$ critical value & Probability \\
\hline 0.996 & $108.150^{*}$ & 22.299 & 0 \\
0.822 & $32.862^{*}$ & 15.892 & 0 \\
0.088 & 1.755 & 9.164 & 0.825 \\
\hline
\end{tabular}

\begin{tabular}{|c|c|c|c|}
\hline \multicolumn{4}{|c|}{$3^{\text {rd }}$ model specification } \\
\hline \multicolumn{4}{|c|}{ Unrestricted cointegration rank test (Trace) } \\
\hline Eigenvalue & $\lambda$ trace statistic & $5 \%$ critical value & Probability \\
\hline 0.995 & $135.398 *$ & 29.797 & 0 \\
\hline 0.822 & $33.554 *$ & 15.494 & 0 \\
\hline 0.038 & 0.751 & 3.841 & 0.386 \\
\hline
\end{tabular}

\begin{tabular}{|c|c|c|c|}
\hline \multicolumn{4}{|c|}{ Unrestricted cointegration rank test (Maximum Eigenvalue) } \\
\hline Eigenvalue & Max-Eigen statistic & $5 \%$ critical value & Probability \\
\hline 0.995 & $101.843 *$ & 21.131 & 0 \\
\hline 0.822 & $32.803 *$ & 14.264 & 0 \\
\hline 0.038 & 0.751 & 3.84 & 0.386 \\
\hline
\end{tabular}

Source: made on EViews 9.

*, indicate that we can't reject the alternative hypothesis.

Table 17

The VECM optimal

\begin{tabular}{l|c|c}
\hline VECM Models & Akaike criterion & Schwarz criterion \\
\hline $1^{\text {st }}$ model & -55.216 & -55.128 \\
$2^{\text {nd }}$ model & -61.930 & -59.444 \\
$3^{\text {rd }}$ model & -61.877 & -59.342 \\
\hline
\end{tabular}

Source: made on EViews 9. 
Table 18

The VECM restricted

\begin{tabular}{lcc}
\hline Cointegration restriction & Chi-square (2) & Probability \\
\hline $\mathrm{A}(1,1)=0$ & $1.89 * 10^{-8}$ & 1 \\
$\mathrm{~A}(1,2)=0$ & $1.70^{*} 10^{-8}$ & 1 \\
$\mathrm{~A}(2,1)=0$ & $3.58^{*} 10^{-8}$ & 1 \\
$\mathrm{~A}(2,2)=0$ & $3.55^{*} 10^{-8}$ & 1 \\
$\mathrm{~A}(3,1)=0$ & $3.49 * 10^{-8}$ & 0.007 \\
$\mathrm{~A}(3,2)=0$ & 12.095 & 0.008 \\
$\mathrm{~A}(1,1)=0, \mathrm{~A}(1,2)=0$ & 17.144 & 0.001 \\
$\mathrm{~A}(1,1)=0, \mathrm{~A}(2,1)=0$ & 15.392 & 1 \\
$\mathrm{~A}(1,1)=0, \mathrm{~A}(2,2)=0$ & $3.75^{*} 10^{-8}$ & 0.981 \\
$\mathrm{~A}(1,1)=0, \mathrm{~A}(3,1)=0$ & 0.177 & 1 \\
$\mathrm{~A}(1,2)=0, \mathrm{~A}(2,1)=0$ & $1.64 * 10^{-6}$ & 0.001 \\
$\mathrm{~A}(1,2)=0, \mathrm{~A}(2,2)=0$ & 15.392 & 0.998 \\
$\mathrm{~A}(1,2)=0, \mathrm{~A}(3,1)=0$ & 0.037 & 0 \\
$\mathrm{~A}(2,1)=0, \mathrm{~A}(2,2)=0$ & 32.264 & 0.021 \\
$\mathrm{~A}(2,1)=0, \mathrm{~A}(3,1)=0$ & 11.459 & 1 \\
$\mathrm{~A}(2,2)=0, \mathrm{~A}(3,1)=0$ & $3.88^{*} 10^{-8}$ & 0.016 \\
$\mathrm{~A}(1,1)=0, \mathrm{~A}(1,2)=0, \mathrm{~A}(2,1)=0$ & 17.144 & 0.996 \\
$\mathrm{~A}(1,1)=0, \mathrm{~A}(2,2)=0, \mathrm{~A}(3,1)=0$ & 0.177 & 0 \\
$\mathrm{~A}(1,2)=0, \mathrm{~A}(2,1)=0, \mathrm{~A}(2,2)=0$ & 32.264 & \\
\hline $\mathrm{S} 0$ & & 1
\end{tabular}

Source: Done on EViews 9.

Table 19

VECM estimation

\begin{tabular}{|c|c|c|c|}
\hline Cointegrating equation & C.E. 1 & C.E. 2 & \\
\hline $\mathrm{GDP}_{\mathrm{t}-1}$ & 1 & 0 & \\
\hline $\mathrm{CO}_{2 \mathrm{t}-1}$ & 0 & 1 & \\
\hline $\mathrm{REC}_{\mathrm{t}-1}$ & $-4.22 * 10^{12 * * *}$ & $-931.420 * * *$ & \\
\hline t-statistic & -5.938 & -5.728 & \\
\hline $\mathrm{C}$ & $2452.788 * *$ & $-1.29 * 10^{-6 * * *}$ & \\
\hline t-statistic & 2.466 & -5.684 & \\
\hline Error correction & DGDP $_{t}$ & $\mathrm{DCO}_{t}$ & DREC $_{t}$ \\
\hline C.E. 1 & 0.007 & $-5.83 * 10^{-11 * * *}$ & $-2.03 * 10^{-13}$ \\
\hline t-statistic & 0.034 & -4.736 & -0.358 \\
\hline C.E. 2 & $-6.37 * 10^{8}$ & $0.265^{* * * *}$ & 0.002 \\
\hline t-statistic & -0.605 & 4.618 & 0.788 \\
\hline DGDP $_{t-1}$ & $-1.392 * * *$ & $1.99 * 10^{-10 * * *}$ & $3.95 * 10^{-13}$ \\
\hline t-statistic & -3.702 & 9.674 & 0.418 \\
\hline DGDP $_{\mathrm{t}-2}$ & $-0.756^{* *}$ & $4.05 * 10^{-11 * *}$ & $-7.62 * 10^{-14}$ \\
\hline t-statistic & -2.629 & 2.582 & -0.105 \\
\hline $\mathrm{DCO}_{2 \mathrm{t}-1}$ & $5.27 * 10^{9 * * *}$ & 0.150 & 0.0001 \\
\hline t-statistic & 3.010 & 1.579 & 0.036 \\
\hline $\mathrm{DCO}_{2 \mathrm{t}-2}$ & $-1.52 * 10^{9}$ & $0.258 * * *$ & -0.0005 \\
\hline t-statistic & -1.133 & 3.534 & -0.167 \\
\hline
\end{tabular}




\begin{tabular}{|c|c|c|c|}
\hline DREC $_{t-1}$ & $-2.62 * 10^{10 *}$ & -5.321 & 0.140 \\
\hline t-statistic & -1.745 & -0.650 & 0.373 \\
\hline DREC $_{\mathrm{t}-2}$ & $-1.63 * 10^{11}$ & $-18.500 * * *$ & -0.018 \\
\hline t-statistic & -1.448 & -3.004 & -0.065 \\
\hline RVFEP $_{\mathrm{t}}$ & $-305048.683^{* *}$ & $3.35 * 10^{-5 * * *}$ & $-2.003 * 10^{-7}$ \\
\hline t-statistic & -2.510 & 5.053 & -0.657 \\
\hline RVFEC $_{t}$ & $754209.079 * * *$ & $4.40 * 10^{-5 * * *}$ & $2.71 * 10^{-7}$ \\
\hline t-statistic & 5.018 & 5.367 & 0.720 \\
\hline $\mathrm{RVREP}_{\mathrm{t}}$ & 10665.55 & $3.46 * 10^{-7}$ & $3.15^{*} 10^{-8}$ \\
\hline t-statistic & 0.950 & 0.565 & 1.118 \\
\hline $\mathrm{RVGDP}_{\mathrm{t}}^{2}$ & 0.399 & $-1.94 * 10^{-11}$ & $6.77 * 10^{-13}$ \\
\hline t-statistic & 1.683 & -1.495 & 1.139 \\
\hline Kyoto $_{\mathrm{t}}$ & 391.348 & $-3.11 * 10^{-8}$ & $1.93 * 10^{-9 * *}$ \\
\hline t-statistic & 1.126 & -1.639 & 2.215 \\
\hline Paris $_{t}$ & $-1249.706 * * *$ & $3.63 * 10^{-8}$ & $-1.65^{*} 10^{-9}$ \\
\hline t-statistic & -3.066 & 1.630 & -1.610 \\
\hline
\end{tabular}

Source: Done on EViews 9.

Table 20

$\operatorname{VECM}(r)$ estimation

\begin{tabular}{|c|c|c|c|}
\hline Cointegrating equation & C.E. 1 & C.E. 2 & \\
\hline $\mathrm{GDP}_{\mathrm{t}-1}$ & 0.003 & -0.001 & \\
\hline $\mathrm{CO}_{2 \mathrm{t}-1}$ & -16830620.898 & 11069512.034 & \\
\hline $\mathrm{REC}_{\mathrm{t}-1}$ & 32970740.193 & $-5.75 * 10^{9}$ & \\
\hline $\mathrm{C}$ & 30.835 & -16.952 & \\
\hline Error correction & DGDP $_{t}$ & $\mathrm{DCO}_{\mathrm{t}}$ & DREC $_{t}$ \\
\hline C.E. 1 & -26.271 & $-1.58 * 10^{-8 * * *}$ & N/A \\
\hline t-statistic & -0.487 & -15.321 & N/A \\
\hline C.E. 2 & $-97.467 * * *$ & N/A & $1.88 * 10^{-10 * * *}$ \\
\hline t-statistic & -3.927 & N/A & 6.976 \\
\hline DGDP $_{\mathrm{t}-1}$ & $-1.392 * * *$ & $1.99 * 10^{-10 * * *}$ & $3.95 * 10^{-13}$ \\
\hline t-statistic & -3.702 & 9.674 & 0.418 \\
\hline DGDP $_{\mathrm{t}-2}$ & $-0.756^{* *}$ & $4.05 * 10^{-11 * *}$ & $-7.62 * 10^{-14}$ \\
\hline t-statistic & -2.629 & 2.582 & -0.105 \\
\hline $\mathrm{DCO}_{2 \mathrm{t}-1}$ & $5.27 * 10^{9 * * *}$ & 0.150 & 0.0001 \\
\hline t-statistic & 3.010 & 1.579 & 0.036 \\
\hline $\mathrm{DCO}_{2 \mathrm{t}-2}$ & $-1.52 * 10^{9}$ & $0.258 * * *$ & -0.0005 \\
\hline t-statistic & -1.133 & 3.534 & -0.167 \\
\hline DREC $_{t-1}$ & $-2.62 * 10^{10 *}$ & -5.321 & 0.140 \\
\hline t-statistic & -1.745 & -0.650 & 0.373 \\
\hline DREC $_{t-2}$ & $-1.63 * 10^{11}$ & $-18.500 * * *$ & -0.018 \\
\hline t-statistic & -1.448 & -3.004 & -0.065 \\
\hline RVFEP $_{\mathrm{t}}$ & $-305048.683 * *$ & $3.35 * 10^{-5 * * *}$ & $-2.003 * 10^{-7}$ \\
\hline t-statistic & -2.510 & 5.053 & -0.657 \\
\hline RVFEC $_{t}$ & $754209.079 * * *$ & $4.40 * 10^{-5 * * *}$ & $2.71 * 10^{-7}$ \\
\hline t-statistic & 5.018 & 5.367 & 0.720 \\
\hline
\end{tabular}




\begin{tabular}{lccc} 
RVREP $_{\mathrm{t}}$ & 10665.55 & $3.46^{*} 10^{-7}$ & $3.15^{*} 10^{-8}$ \\
t-statistic $^{-8}$ & 0.950 & 0.565 & 1.118 \\
RVGDP $_{\mathrm{t}}^{2}$ & 0.399 & $-1.94 * 10^{-11}$ & $6.77 * 10^{-13}$ \\
t-statistic & 1.683 & -1.495 & 1.139 \\
Kyoto $_{\mathrm{t}}$ & 391.348 & $-3.11^{*} 10^{-8}$ & $1.93 * 10^{-9 * *}$ \\
t-statistic $^{-9}$ & 1.126 & -1.639 & 2.215 \\
Paris $_{\mathrm{t}}$ & $-1249.706^{* * *}$ & $3.63 * 10^{-8}$ & $-1.65^{*} 10^{-9}$ \\
t-statistic & -3.066 & 1.630 & -1.610 \\
\hline
\end{tabular}

Source: Done on EViews 9.

$*, * *,{ }^{* * *}$, indicate that we can't reject the alternative hypothesis and the coefficients are significant at $10 \%, 5 \%$ or $1 \%$.

\section{Inverse Roots of AR Characteristic Polynomial}

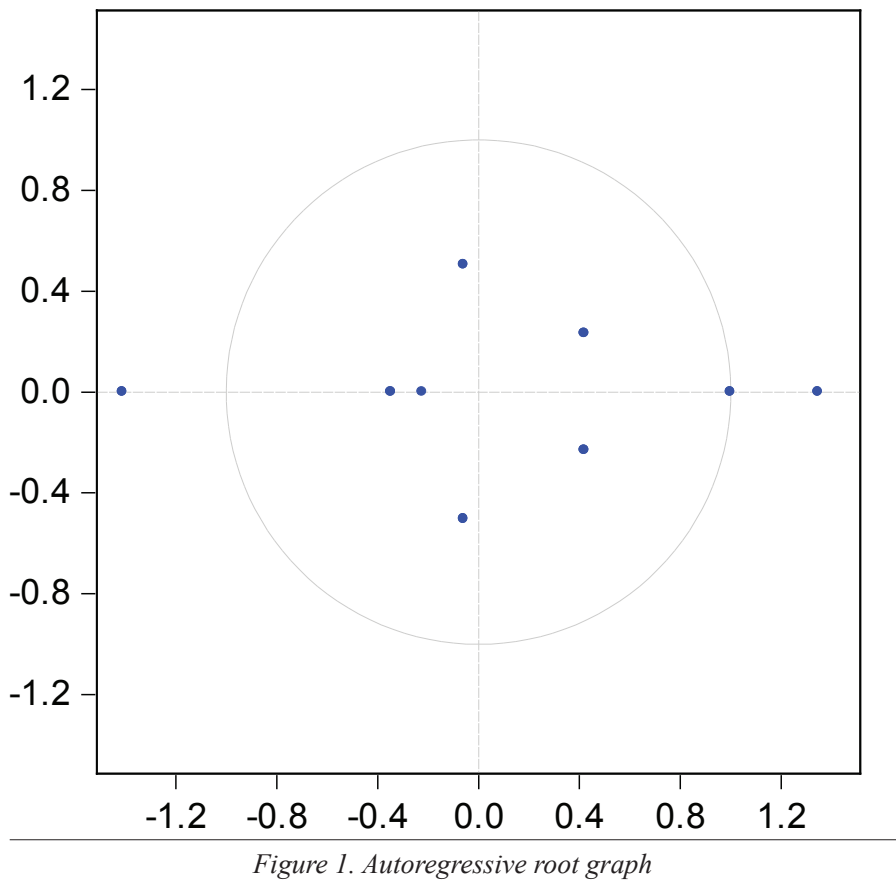

Source: done on EViews 9

Table 21:

Multivariate normality tests

\begin{tabular}{l|c|c}
\hline Component & Jarque-Bera & Prob \\
\hline 1 & 6.467 & 0.039 \\
2 & 0.689 & 0.708 \\
3 & 2.660 & 0.264 \\
Joint & 9.817 & 0.132 \\
\hline
\end{tabular}

Source: Done on EViews 9 

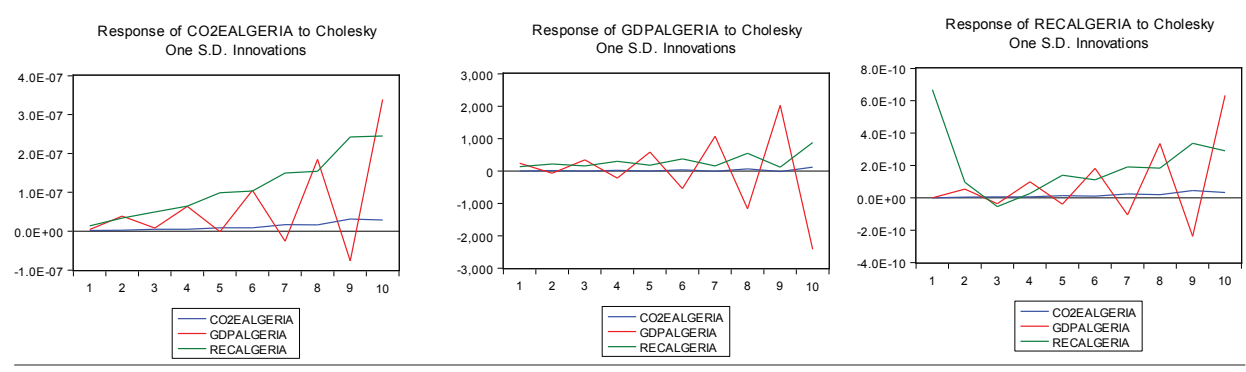

Figure 02. Impulse response with Cholesky decomposition

Source: Done on EViews 9.

Table 22

Impulse response to Cholesky of $\left(\mathrm{CO}_{2}\right)$

\begin{tabular}{lccc}
\hline Period & $\mathbf{C O}_{2}$ & GDP & REC \\
\hline 1 & $1.72 * 10^{-9}$ & $4.11^{*} 10^{-9}$ & $1.39 * 10^{-8}$ \\
2 & $2.44 * 10^{-9}$ & $3.86 * 10^{-8}$ & $3.38^{*} 10^{-8}$ \\
3 & $4.74 * 10^{-9}$ & $7.91 * 10^{-9}$ & $4.96 * 10^{-8}$ \\
4 & $4.85^{*} 10^{-9}$ & $6.36 * 10^{-8}$ & $6.45^{*} 10^{-8}$ \\
5 & $9.02 * 10^{-9}$ & $-1.04 * 10^{-9}$ & $9.88^{*} 10^{-8}$ \\
\hline
\end{tabular}

Source: Done on EViews 9

Table 23

Impulse response to Cholesky of (GDP)

\begin{tabular}{lccc}
\hline Period & $\mathbf{C O}_{2}$ & GDP & REC \\
\hline 1 & 0 & 233.657 & 128.77 \\
2 & 7.979 & -70.809 & 214.073 \\
3 & -2.313 & 342.884 & 156.467 \\
4 & 16.124 & -225.012 & 297.622 \\
5 & -4.793 & 585.216 & 179.345 \\
\hline Source: Done on EViews 9 & & &
\end{tabular}

Table 24

Impulse response to Cholesky of (REC)

\begin{tabular}{lccc}
\hline Period & $\mathbf{C O}_{2}$ & GDP & REC \\
\hline 1 & 0 & 0 & $6.69 * 10^{-10}$ \\
2 & $3.86^{*} 10^{-12}$ & $5.41 * 10^{-11}$ & $9.68^{*} 10^{-11}$ \\
3 & $5.99^{*} 10^{-12}$ & $-3.70^{*} 10^{-11}$ & $-5.42^{*} 10^{-11}$ \\
4 & $5.35^{*} 10^{-12}$ & $9.84^{*} 10^{-11}$ & $2.71^{*} 10^{-11}$ \\
5 & $1.31 * 10^{-11}$ & $-3.90 * 10^{-11}$ & $1.40^{*} 10^{-10}$ \\
\hline
\end{tabular}

Source: Done on EViews 9 
Table 25

Variance decomposition (CO2)

\begin{tabular}{lccc}
\hline Period & GDP & CO $_{2}$ & REC \\
\hline 1 & 7.965 & 1.400 & 90.635 \\
2 & 52.872 & 0.313 & 46.815 \\
3 & 29.069 & 0.581 & 70.35 \\
4 & 41.154 & 0.403 & 58.443 \\
5 & 23.911 & 0.58 & 75.509 \\
\hline Source: Done on EViews 9 & & &
\end{tabular}

Table 26

Variance decomposition (GDP)

\begin{tabular}{l|c|c|c}
\hline Period & GDP & CO2 & REC \\
\hline 1 & 76.703 & 0 & 23.297 \\
2 & 48.827 & 0.052 & 51.121 \\
3 & 67.078 & 0.026 & 32.896 \\
4 & 56.443 & 0.082 & 43.475 \\
5 & 73.276 & 0.045 & 26.679 \\
\hline \multicolumn{2}{l}{} \\
\hline
\end{tabular}

Table 27

Variance decomposition (REC)

\begin{tabular}{lccc}
\hline Period & GDP & CO $_{2}$ & REC \\
\hline 1 & 0 & 0 & 100 \\
2 & 0.638 & 0.004 & 99.358 \\
3 & 0.927 & 0.011 & 99.062 \\
4 & 2.948 & 0.017 & 97.035 \\
5 & 3.129 & 0.051 & 96.820 \\
\hline Source: Done on EViews 9 & & & \\
\hline
\end{tabular}


